\title{
IIIIII 創薬研究の新潮流35
}

創 薬

シリーズ(8)

\section{次世代ゼブラフィッシュ創薬と プレシジョンメディシン}

田中 利男 ${ }^{1,2)}$ ，小岩 純子 $^{1)}$
要約 : 21 世紀の本格的ゲノム創薬時代に突入してか らも，難治性疾患（アンメットメディカルニーズ）に 対する画期的治療薬（First-in-Class）開発は，困難を 極めてきたが，米国 FDA に承認された $62 \%$ の画期的 新薬は, フェノタイプスクリーニングにより見出され ている。次世代ゼブラフィッシュ創薬は，ハイスルー プット in vivo フェノタイプスクリーニングを可能に し, 現在グローバルな創薬戦略にインパクトを与えて いる．高度免疫不全マウスに比較して，ゼブラフィッ シュによる患者がん移植の生着率の高さや生着速度の 速さから, 抗がん薬選択のための臨床体外診断システ ムとして，真の個別化医療ツールになることが期待さ れている. 従来の個別化医療のオミクス基盤に加え, 患者がん移植ゼブラフィッシュによる個別化医療は, その患者の治療薬選択に活用する真の次世代プレシ ジョンメディシンであり, 大きなパラダイムシフトが 実現しつつある.

\section{21 世紀ゲノム創薬時代における最重要課題}

21 世紀に本格的ゲノム創薬時代へ突入してから, 現 在もな抢治療が困難なアンメットメディカルニーズの 高い疾患に対する画期的治療薬（First-in-Class）開発 は，依然として渋難を極めている。具体的には，2008 年から 2010 年における世界の臨床試験第 II 相試験の 成功率はわずか $18 \%$ であり, 国際的に最も深刻な問題 として受け止められている. これら失敗原因の多くが, 不十分な薬効であることから，従来のゲノム創薬にお けるリバース薬理学がその役割を果たしきれていない ことが，特に問題視されるようになった(1).

新薬開発に招ける危機的状況に対して米国 NIH が, この困難性に対する研究戦略イノベーションとして
2011 年 10 月に, 定量的システムズ薬理学 (Quantitative and Systems Pharmacology） 白書を報告し，世界にイ ンパクトを与えた (2).この白書によれば，定量的シ ステムズ薬理学とは, 薬理学, ゲノム医学, 情報科学 が統合されたもので，多くの革新的挑戦を挙げており， 中でも新しい挑戦的創薬ツールとして，ゼブラフィッ シュや iPS 細胞などが提案されている. ゼブラフィッ シュ創薬は, 脊椎動物の in vivo ハイスループットスク リーニングを有史以来初めて創薬プロセスに提供して おり, グローバルな創薬戦略にインパクトを与え, 明 白なパラダイムシフトが実現してきている (3). 一方, 1999 年〜2008 年において米国 FDA に認可された新薬 を解析すると, 興味深いことに $62 \%$ の画期的新薬 （First-in-Class）は，フェノタイプスクリーニングによ り見出され確立していることが明らかとなった(4). その結果, 現状のターゲットベースなリバース薬理学 の限界を克服するために定量的 in vivo フェノタイプ スクリーニングが注目されることとなり，生体レベル でのフェノタイプやメカニズムの定量的八イスルー プットスクリーニングが可能なゼブラフィッシュへの 期待が大きくなっている（図 1).

\section{2. ゼブラフィッシュ創薬によるパラダイム シフト（図 1,2$)$}

ゼブラフィッシュの医学研究活用は, PubMedに 1948 年から報告されていたが, 2017 年は 2898 報にな り 2018 年にはさらに論文が増加すると思われる。こ れらの研究成果は, ゼブラフィッシュ創薬に重要な基 盤情報を与えている（図 1)。現在までの創薬は，ハイ スループットが可能な iPS 細胞や ES 細胞などのヒト 細胞や, ロースループットながら梁い in vivo メカニズ

キーワード：ゼブラフィッシュ創薬，ライブ in vivo フェノタイプスクリーニング，個別化医療，プレシジョンメディシン， 薬理フェノミクス

1) 三重大学大学院 医学系研究科 システムズ薬理学, ${ }^{2)}$ 三重大学メディカルゼブラフィッシュ研究センター ( ( $514-8507$ 三重県津市江戸橋 2-174)

E-mail: tanaka@doc.medic.mie-u.ac.jp＼cjkstart原稿受領日：2019 年 4 月 5 日，依頼原稿 


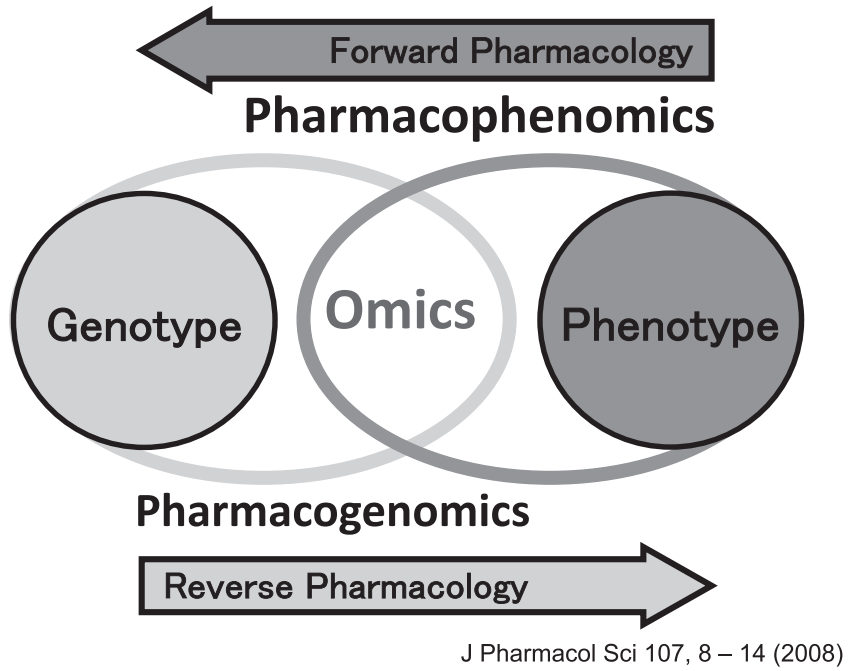

図 1 薬理フェノミクスによるゼブラフィッシュ創薬

ム解析に活用してきた哺乳類モデルが 2 大モデル生物 であった。 そして，ゼブラフィッシュは in vivo ハイス ループットスクリーニングが実現する唯一のモデル春 椎動物であり, 創薬モデル生物の第三極を形成し, 全 く新しいパラダイムを実現することになる.

ここで，ゼブラフィッシュについて簡単に述べてお こう，春椎動物であるゼブラフィッシュは，ヒト疾患 ゲノムにおける相同性が約 $80 \%$ ある。 ゼブラフィッ シュ肧は, 受精後 1 日で心拍動が認められる等, 臟器 形成が著しく早く，また，交配時には 1 組 1 回で約 200 個の受精卵を得ることができる。 そして, 受精卵 も含め, 体長 $3 \mathrm{~mm}$ の稚魚は透明で, 精密なフェノタ イプ解析を可能にし，96 穴プレートを用いれば, $1 \mathrm{mg}$ 以下の各化合物でin vivo に扔ける薬効と安全性の大 規模スクリーニングが完了できる．また，動物愛護と の調和性が高く, 欧米では早くから活用されている.

実際ヨーロッパでは 2008 年からはラットを抜いて, ゼブラフィッシュがマウスの次に頻用されているモデ ル生物となっている. さらに，世界中で多数のゼブラ フィッシュ創薬ベンチャーが創業しており, また，国 際的メガファーマが, 薬効・安全性研究でゼブラ フィッシュを積極的に活用している。 ここでは初期に ゼブラフィッシュフェノタイプスクリーニングが新薬 開発に著効した成功 5 例を紹介する.

(1)ゼブラフィッシュスクリーニングによりプロスタグ ランジン $\mathrm{E} 2$ 安定誘導体が造血幹細胞を増加させる 化合物として 2007 年に報告された $(5)$ 。これはゼブ ラフィッシュ創薬のフロントランナーであり, 2014 年の臨床試験第 II 相においては, 白血病とリンパ腫 における臍帯血移植前の ex vivo 調製薬として使用
されている(6).

(2) ORC-13661 は, 米国ワシントン大学 (シアトル)に おいてゼブラフィッシュに拈けるアミノグリコシド 性難聴に対する予防薬として開発され，アミノグリ コシドによる有毛細胞死を防止する化合物として臨 床試験に突入している (7).

(3)ゼブラフィッシュ創薬によるオーファンドラッグの 典型例としての EPX-300 は, Dravet症候群の希少疾 病用医薬品として米国 FDA から指定を受けた.

(4) 2009 年に, ゼブラフィッシュ急性骨䯣性白血病モ デルによる既存薬スクリーニングから， シクロオキ シゲナーゼ（COX）2 阻害薬の有効性が発見された (8). そして, 急性骨䯣白血病と骨髄異型性症候群 の COX 阻害薬による臨床試験が開始されている (9). (5) kcnh2 遺伝子変異によるゼブラフィッシュ LQTtype2 症候群モデルによる 1200 の既存薬スクリーニング の結果, 糖質コルチコイド flurandrenolide に強力な 薬効が見出された $(10)$.

特筆すべきことに，これら 5 例はすべてヒト病態モ デルゼブラフィッシュによるフェノタイプスクリーニ ングがスタート点になっている，すなわち従来のオミ クス解析から決定した創薬ターゲットによるリバース 薬理学が, 現状ではあまりに確率が悪い状況にあり， 画期的新薬の $62 \%$ がフェノタイプ創薬で見出されて いること，つまり現代オミクス医学において，ヒト臨 床病態情報から臨床的に有効な創薬ターゲットにたど り着く分子還元主義の確率が高くないことを明確に示 唆していることになる。この苦境を打破する創薬戦略 として, ヒト臨床病態を可能な限り正確に面（フェ） タイプ）として写し取るヒト病態モデルゼブラフィッ シュによるフェノタイプスクリーニングが注目され， シード化合物の発見に利用されてきている（全体像： 図2).

以上の実績から，ゼブラフィッシュ創薬は，単なる 安価なマウスや追加的薬理試験ではなく, フォワード 薬理学とリバース薬理学を統合したものであり, 最終 的には強力な PK/PD モデルとして構築され, 真に 21 世紀的システムズ薬理学戦略であることが明らかであ る. 特にゼブラフィッシュ創薬の原理的な特徵は, ヒ 卜臨床病態を正確に写し取ったヒト病態モデルゼブラ フィッシュによるフェノタイプスクリーニングから開 始することであり, 薬理フェノミクスを創薬エンジン とする新世代フォワード薬理学として確立されつつあ る. またゼブラフィッシュ創薬は, 単なる遺伝子や夕 ンパク質ネットワークの相互作用の変化をシュミレー ションするといったシステムズ生物学の薬理応用で 


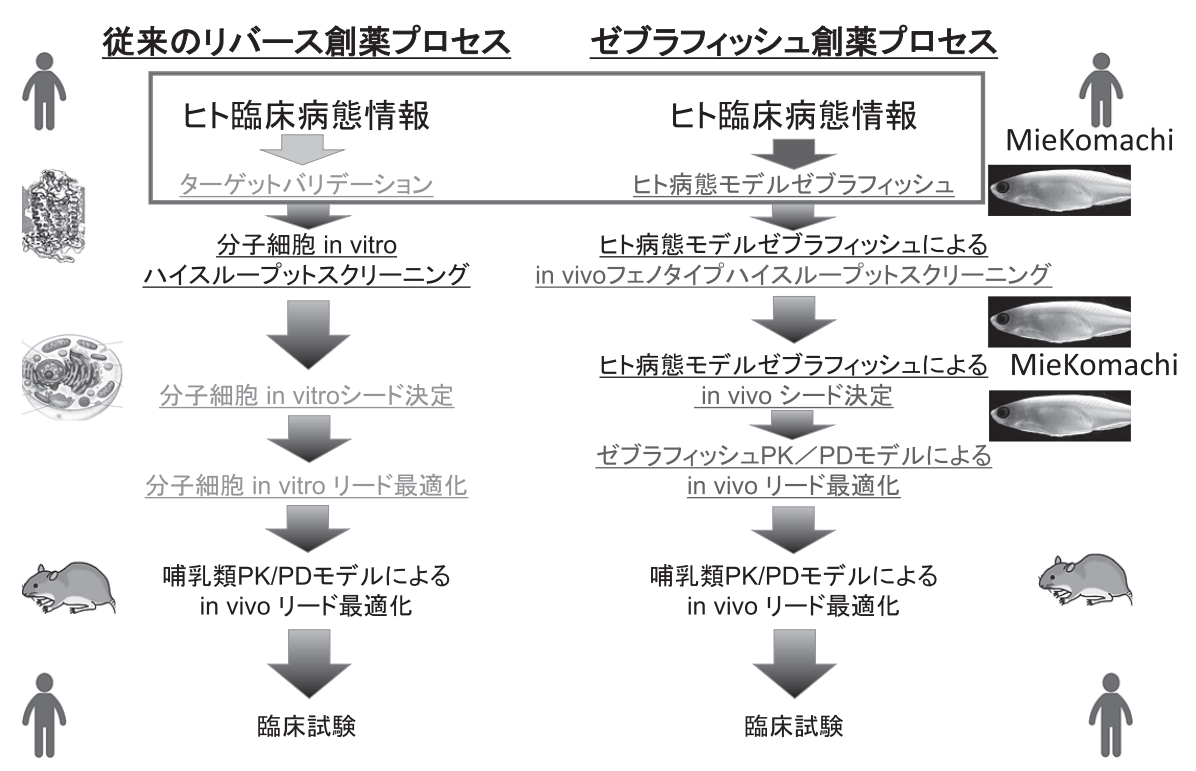

図 2 従来のリバース創薬プロセスとゼブラフィッシュ創薬プロセスのパラダイム比較

はなく，全く新しい創薬パラダイム（図 1 , 図 2) を, 我々に提示してくれている。 そして，ゼブラフィッ シュ創薬は確実に第三極の開発戦略を提供しており, 今後創薬全体への影響が明らかになると思われ，わが 国でも先進的な製薬や食品おける取り組みがなされ, 発展が期待されている.

\section{3. 次世代ゼブラフィッシュ創薬への革新}

ゼブラフィッシュ創薬は, 創薬戦略にパラダイムシ フトを確実に起こしているが，まだ国際的に 10 年余 の歴史しかなく技術的にも経験的にも未熟な部分を多 く残しているため, 本来持っているポテンシャルを引 き出せていない可能性がある。そこでまず，ゼブラ フィッシュ創薬のプロセスの強化が必須であると考え る. 特に(1)広範なヒト病態モデルの拡充と高度化, (2)ゼブラフィッシュ病態フェノミクス解析の先端技術, (3) in vivo ハイスループットスクリーニングの自動化, 定量化, 高速化, 高度化は, ゼブラフィッシュ創薬の 成否を決める最重要技術革新であり,それら 課題についての現状と取るべき対策について述べる. ただし，これらの実現には，膨大な情報を必要とし， IoTのゼブラフィッシュ版である Internet of Zebrafish (IoZ) 展開によるビッグデータの $\mathrm{AI}$ 創薬への発展が不 可欠となるのは想像に難くない.

(1)ヒト病態モデル創生には, ヒト化などの高度化と 種類の多様性が必要条件となっている。まず他の種で も可能となったゲノム編集技術 (ZFN, TALEN, CRISPRなど）により，ゼブラフィッシュでも広範な ヒト疾患遺伝子のノックアウトやノックインが容易に
なされ，多様な単一遺伝子疾患モデルが開発されてい る。一方，ゼブラフィッシュ薬物動態遺伝子のノック アウトおよびヒト薬物動態遺伝子のノックインなどに より全身の薬物動態をできるだけヒト化することが可 能になりつつあり，さらにヒト iPS 細胞などの移植に よるヒト化キメラゼブラフィッシュの創生により組織 レベルでのヒト化ゼブラフィッシュが実現しつつある (図 2).

(2)ゼブラフィッシュ病態フェノミクス解析技術は, ゼブラフィッシュ創薬のコアテクノロジーの一つで, ゼブラフィッシュ創薬に招いて定量的フェノタイプ解 析がスタート点であることからすべてを決定する重要 な基盤技術となる（図 1 , 図 2). 脊椎動物であるゼブ ラフィッシュは, 多くの場合ヒト臨床フェノタイプと の類似性やそのオミクス機構に扔ける相同性も期待さ れている。すすわち, ゼブラフィッシュ病態モデルの 定量的フェノタイプスクリーニングの新しいポテン シャルとしてスループットとフェノタイプ外挿性を同 時に実現していることから, ヒト臨床オミクスに外挿 した薬効定量解析が可能となる。 しかしながら, 現時 点ではオミクス基盤における外挿性が保証された疾患 フェノタイプモデル（すなわちゼブラフィッシュ疾患 モデルフェノミクス）が不十分であり，その先端化と 拡充が, 緊急課題となっている(11-15).

(3)脊椎動物でライブ in vivo スクリーニングがハイ スループットで実現することが，ゼブラフィッシュ最 大の特徴であることは明らかである. 国際的に 2000 年から, 96 ウエルプレートによるゼブラフィッシュス クリーニングが開始されたが，現在我々は 1536 ウエ 
ルプレートゼブラフィッシュスクリーニングシステム などを目的別に開発している，具体的には，ゼブラフ イッシュ創薬の成否を決める受精卵品質管理プロトコ ルを，世界で初めて 1536 ウエルプレート受精卵タイ ムラプス共焦点イメージングにより確立してきてい る。このシステムは, サリドマイドなどの発生毒性メ カニズム解析 (16-21) に, 新しい洞察を可能にしてい る。ゼブラフィッシュ疾患ゲノム全体はヒトと約 80\%の相同性があるとされているが，この差異はむし ろヒト臨床がん細胞移植部位の宿主ゼブラフィッシュ 微小環境とヒト移植がん細胞の次世代 DNA シークエ ンサー（RNAseq）などによる相互作用解析に有利な 点ともいえる(22-24). TALEN や CRISPRによるゲノ ム編集がゼブラフィッシュにも高効率に応用できるこ となどから, 創薬ターゲットバリデーションや新薬作 用機構の解明に抢けるスループットを圧倒的に高くし ている。 これまでにも我々は, Dravet症候群や筋ジス トロフィーなどの単一遺伝子疾患モデルに加えメタボ リックシンドロームや心不全などの生活習慣病モデル を多数創生し，メカニズムや化合物のスクリーニング を展開している $(25-37)$. さらに, 種々の色素欠損ラ インと細胞選択的蛍光タンパク質トランスジェニック ゼブラフィッシュとの交配などにより, 各ヒト病態モ デルのライブ in vivo イメージング用ゼブラフィッシ ユを現時点で 64 種類（MieKomachi シリーズ）開発 し, 定量的フェノタイプスクリーニングに活用してき ている $(22,23,30,32)$. 一方で, トランスジェニック ゼブラフィッシュでカバーできない生体内細胞ライブ in vivo イメージング用プローブを多数創製し, 各病態
イメージングに活用している(37-41)。これらの基盤 技術をさらに強化して, オミクス研究の急速な発展に 対応できる独自に開発したZFplate を核にフェノミク ス解析システムを構築するため, ライブ in vivo イメー ジングをコアに, 高速化, 定量化, 高度化等によるフ ル自動化と Internet of Zebrafish（ゼブラフィッシュ版 の IoT) やAI 創薬の実現を目指している.すなわち, 行動や in vivo イメージングなどのフェノタイプ解析 における膨大な変数項目測定を可能にし，オミクスと の相関解析を実現し，新しいメカニズム解明を実現し ている.さらに，ヒトがん幹細胞移植モデルを確立し て(24), 新規蛍光ヒトがん幹細胞阻害薬を発見し, ヒ 卜がん幹細胞におけるステムネス機構を解析している (42).

\section{4. ゼブラフィッシュ創薬とプレシジョンメディ シン (図 3)}

2015 年米国前大統領オバマによる Precision Medicine Initiativeにより，グローバルにも先端がん個別化医療 としてのプレシジョンメディシンが急速に展開されて いる. 現在のプレシジョンメディシンの主な基盤は患 者のオミクス情報であり, 薬物治療応答性を予測しょ うとするものである. しかし, 患者オミクス情報と既 知の医学医療情報による個別化医療は統計学的予測に 依存するため, その精度向上には, 多数の患者の大量 のオミクス情報が不可欠であり, 膨大なコストと時間 が不可欠となる。一方, ゼブラフィッシュ創薬の有効 性が明らかになりつつある薬理フェノミクスとして, 先端がんプレシジョンメディシンに扔いては, 患者が

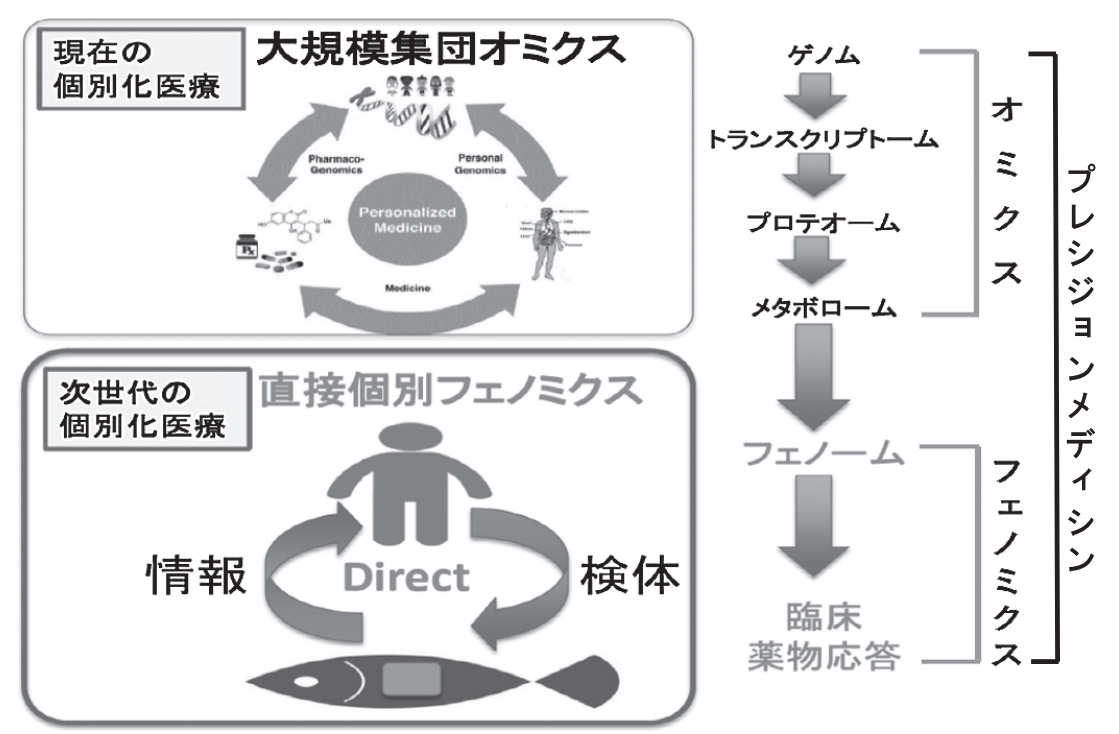

図 3 オミクス個別化医療とフェノミクス個別化医療システムの原理 
ん移植モデル (Patient-Derived Xenograft Model : PDX) を活用することが国際的に急激な発展を示している. 1970 年代から米国 NCI で開始されたヒト臨床がん細 胞培養による新しい治療薬開発は満足すべきものでな いことから，国際的にも患者がん移植モデルへ大きく シフトしょうとしている $(43,44)$.

現在世界では高度免疫不全マウスによる患者がん移 植モデル（PDX mouse model）が圧倒的に活用されて いるが，いくつかの課題があり，正常免疫であるゼブ ラフィッシュによる新しい患者がん移植モデル動物 （PDX zebrafish model）として我々などが挑戦してい る。すなわち高度免疫不全マウスと比較して，ゼブラ フィッシュへの患者がん移植の圧倒的な生着率や生着 スピードが，免疫システムが未熟な受精後 36 時間以 内に移植すれば速いこと, 移植に必要なヒトがん細胞 が 100 個以下であり，2 日間で薬効が定量解析できる などの利点から，我々をはじめ世界で患者がん検体の ゼブラフィッシュ移植が試みられている。これらヒト 臨床がん細胞のゼブラフィッシュ移植システム（PDX zebrafish model）は, PDX mouse model より圧倒的に 迅速な治療薬感受性試験が実現しており, 抗がん薬選 択のための臨床体外診断システムとして, 次世代個別 化医療ツールになることが明らかにされている（図 3). 従来の個別化医療は, 遺伝子多型 (ゲノム), 遺伝子発 現レベル（トランスクリプトーム），プロテオーム，メ タボロームなどのオミクスを基盤とした大規模集団統 計学の予測により構築されようとしてきた。一方，臨 床がん移植ゼブラフィッシュによる個別化医療は, 各 患者がん検体のフェノミクス解析結果をその患者の治 療薬選択にリアルタイムで活用することができ，真の 次世代プレシジョンメディシンであるといえよう.

\section{文 \\ 献}

1) Arrowsmith J. Nat Rev Drug Discov. 2011;10:328-329.

2) http://www.nigms.nih.gov/training/documents/ systemspharmawpsorger2011.pdf

3) MacRae CA, et al. Nat Rev Drug Discov. 2015;14:721-731.

4) Swinney DC, et al. Nat Rev Drug Discov. 2011;10:507-519.

5) North TE, et al. Nature. 2007;447:1007-1011.

6) Hagedorn EJ, et al. Exp Cell Res. 2014;329:220-226.

7) Chowdhury S, et al. J Med Chem. 2018:61:84-97.

8) Yeh JR, et al. Nat Chem Biol. 2009;5:236-243

9) Klimek VM, et al. Leuk Res. 2012;36:570-574.

10) Peal DS, et al. Circulation. 2011;123:23-30.

11) Kasahara K, et al. Nat Commun. 2018:9:758

12) Ashikawa Y, et al. Heliyon. 2017;3:e00266.

13) Oka T, et al. BMC Physiol. 2010;10:21-33

14) Hiramitsu M, et al. Sci Rep. 2014;4:3708.

15) Nishimura $Y$, et al. Front Pharmacol. 2015;6:257.

16) Kawabata M, et al. Toxicol Sci. 2015;143:374-384.

17) Sasagawa S, et al. Front Pharmacol. 2016;7:57.

18) Inoue A, et al. Fundam Toxicol Sci. 2016;3:79-87.

19) Nishimura $Y$, et al. Congenit Anom (Kyoto). 2016;56:18-27.

20) Nishimura Y, et al. Congenit Anom (Kyoto). 2015;55:1-16.

21) Nishimura $Y$, et al. Front Pharmacol. 2015;6:199.

22) Shimada Y, et al. Methods Mol Biol. 2014;1165:223-238.

23) Zhang B, et al. Tumour Biol. 2014;35:11861-11869.

24) Zhang B, et al. PLoS One. 2014;9:e85439.

25) Ashikawa Y, et al. Front Pharmacol. 2016;7:206.

26) Sasagawa $S$, et al. Front Pharmacol. 2016;7:162.

27) Sasagawa $S$, et al. Front Pharmacol. 2016;7:142.

28) Kawase R, et al. Front Pharmacol. 2016;7:126.

29) Sasagawa S, et al. Front Pharmacol. 2016;7:119.

30) Zhang B, et al. Transl Res.2016;170:89-98

31) Liu F, et al. Stroke. 2014;45:3698-3703.

32) Kuroyanagi J, et al. FEBS Lett. 2014;588:3409-3416.

33) Shimada Y, et al. Nutr Metab (Lond). 2015;12:17.

34) Hasumura T, et al. Nutr Metab (Lond). 2012;9:73

35) Tainaka T, et al. Nutr Metab (Lond). 2011;8:88.

36) Shimada Y, et al. Int J Obes (Lond). 2013;38:1053-1060

37) Nishimura Y, et al. ACS Chem Neurosci. 2013;4:1183-1193

38) Watanabe K, et al. BMC Neurosci. 2016;11:116.

39) Watanabe K, et al. BMC Neurosci. 2012;13:101.

40) Shimada Y, et al. PLoS One. 2012;7:e52549.

41) Umemoto N, et al. Mol Biotechnol. 2013;55:131-142.

42) Zhang B, et al. Biomaterials. 2015;52:14-25.

43) Hidalgo M, et al. Cancer Discov. 2014;4:998-1013.

44) Letai A. Nat Med. 2017;23:1028-1035.

著者の利益相反：開示すべき利益相反はない. 


\title{
Next generation zebrafish-based drug discovery and precision medicine
}

\author{
Toshio Tanaka $^{1,2)}$, Junko Koiwa ${ }^{1)}$ \\ ${ }^{1)}$ Department of Systems Pharmacology, Mie University Graduate School of Medicine \\ ${ }^{2}$ Mie University Medical Zebrafish Research Center
}

\begin{abstract}
Even after entering the era of genomic drug discovery in the 21 st century, development of a breakthrough therapeutic drug (first-in-class) for intractable diseases (unmet medical needs) has been extremely difficult, but to the US FDA $62 \%$ of the approved first-in-class drugs are found by phenotypic screening. The next-generation zebrafish drug discovery enables high-throughput quantitative live in vivo phenotypic screening, and has been impacting global drug discovery strategies now. Compared to severe immunodeficient mice, zebrafish is expected to become a true individualized medical tool as a clinical ex vivo diagnostic system because of the high efficiency and speed of engraftment of patient-derived cancer xenotransplantation. Phenomics-based personalized medicine with the patient-derived cancer xenograft zebrafish in addition to conventional omics platform of individualized medicine is a true next-generation precision medicine to utilize for selection of therapeutic drugs and decision of their doses for the patient, and emerging paradigm shift is realizing in this century.
\end{abstract}

